Council, stated on January 28 that about $£ 40,000$ of the additional $£ 91,000$ allocated to research associations by the Department of Scientific and Industrial Research during the present financial year is for providing increased grants for a number of existing associations and initial grants to the Chalk, Lime and Allied Industries Research Association, the British Steel Castings Research Association and the Timber Development Research Council. The remainder is for capital grants to the Electrical Research Association and the Production Engineering Research Association. On February 1, Mr. Bevins added that in the financial year 1950-51 capital grants of $£ 271,000$ were made to research associations; in $1951-52, £ 53,000$; in $1952-53, £ 17,000$; in 1953-54, $£ 2,000$. It was expected to make no capital payments in the present financial year. Industries were asked to undertake to raise special contributions over and above their normal revenue contributions to the research associations, and the estimates of the total cost have to be submitted to the Department of Scientific and Industrial Research for approval. $\mathrm{He}$ also referred to the special surveys of the resources, facilities and programmes of the leather, cast iron and ceramics research associations, which were carried out as an experiment in 1950-51; a survey of the work of the British Scientific Instrument Research Association has just been started.

The affairs of the Department of Scientific and Industrial Research were again the subject of questions in the House of Commons on February 8. Mr. Bevins stated then that only about five per cent of the Department's work is directly undertaken for defence, and that is normally paid for by the Defence Department. In a written answer, he said that the staff establishment at the Fuel Research Station in 1953-54 was 292 and the expenditure $£ 268,535$, compared with 311 and $£ 295,550$, respectively, in 195455. Asked for an estimate of the expenditure of the Department in terms of 1946 values, he gave the following figures for gross expenditure based on the price index for all consumer goods and services calculated by the Central Statistical Office annually.

$\begin{array}{rrrr}1944-45 & £ 1,491,000 & 1949-50 & \$ 3,662,000 \\ 1945-46 & 1,685,000 & 1950-51 & \mathbf{4}, 019,000 \\ 1946-47 & 2,208,000 & 1951-52 & 4,035,000 \\ 1947-48 & \mathbf{2 , 8 2 5 , 0 0 0} & 1952-53 & 4,085,000 \\ 1948-49 & \mathbf{3}, 198,000 & 1953-54 & \mathbf{4 , 0 7 6 , 0 0 0}\end{array}$

Referring to the Geological Survey, he said that about 60 per cent of England and Wales, 90 per cent of Scotland and all Northern Ireland have been sur. veyed in detail, but he could not state when the survey would be completed.

\section{Earth Tremors in Quetta}

A sWARM of strong earth tremors, about forty in number, starting about February 13 and continuing on February 20, has affected the district around Quetta. Damage to the water supply system and a temporary breakdown of electricity supplies and telephone communications are reported; and there has been damage to property, with some fatal casualties. There is some apprehension in the district, since many remember the earthquakes of May 1935 when some twenty-five thousand people were killed.

\section{Journal of the West African Science Association}

Berore the Second World War, some excellent scientific work was done in the British West African territories; but the number of research workers was small, they were mostly in government service with much of their time taken up in routine work, and there was little difficulty in finding an outlet for the publication of results in the existing journals. Since the War, the establishment of the new University Colleges in the Gold Coast and in Nigeria, and the development and expansion of the independent research institutes dealing with trypanosomiasis, virus diseases, cocoa, oil palms, fisheries, etc., has greatly increased the volume of original work, at a time when existing journals are crowded and publication of new work is often long delayed. A new publication, the Journal of the West African Science Association (1, Part 1; October 1954. Pp. $72+$ 1 plate. London: Charles Knight and Co., Ltd. $21 s$. per vol. (2 parts)), is intended to serve as an outlet for work dealing with West Africa as a whole. It is well produced (printed in Englend), and the papers in the first number reach the standard required by most established journals. They cover a wide field-the geography of Nigeria's coastline, the geology of the Achimota College cricket field, land utilization, check lists of molluses and seaweeds, new records of flowering plants, and a review of recent work on soil fertility. It is stated that one reason for producing this new journal is that "it is convenient for research workers to have their papers on this area readily available within one journal". This can only be true to a limited extent. If reviews of interest to scientific workers generally are to form the journal's main contents that will be true, and the paper on soil fertility (by $\mathrm{P}$. $\mathrm{H}$. Nye) fulfils this object; but the other papers are more specialized, and it is difficult to imagine that many members of the West African Science Association will read more than one or two with interest or understanding. Research as a whole is bound to be specialized, however much this may be deprecated, and by trying to cover too wide a field this journal might defeat its object. However, West Africa is developing rapidly and there is certainly room for this and more journals like it; it is probable that as it grows it will be necessary to divide it into various sections dealing with different subjects, and perhaps later on it will become the parent of a distinguished family of scientific publications.

\section{Bulletin of the Research Council of Israel}

THE Israel Research Council was set up some years ago to organize and stimulate research in all branches of science and technology and to co-ordinate the work of the many scientific institutes in the country. The Bulletin of the Research Council of Israel is published quarterly (Jerusalem: Israel Scientific Press. Annual subscription, I $£ 4.000,5.50$ dollars) and contains original papers as well as preliminary communications in the form of "Letters to the Editor". Papers are submitted in English or French, and summaries of them are collected together at the back of each issue, where they can be easily consulted. Volume 4, No. 1 (June 1954) contains nineteen papers, of which several are on biochemical or chemical topics. Three of these papers are contributions from American laboratories and the rest are from workers in the Hebrew University, the Israel Institute of Technology, the Weizmann Institute or other laboratories in Israel. L. Picard, of the Israel Geological Institute, has written an interesting article on the structural pattern of Palestine, and there are two papers of technological interest as well as others on botanical 